University of Nebraska - Lincoln

DigitalCommons@University of Nebraska - Lincoln

Faculty Papers and Publications in Animal

Science

Animal Science Department

2009

\title{
Effects of Ractopamine (Optaflexx) Fed in Combination with Melengestrol Acetate on Feedlot Heifer Performance
}

\author{
W. A. Griffin \\ University of Nebraska-Lincoln \\ G. E. Erickson \\ University of Nebraska-Lincoln, gerickson4@unl.edu \\ B. D. Dicke \\ Cattlemen's Nutrition Services, Lincoln, NE \\ T. J. Klopfenstein \\ University of Nebraska-Lincoln, tklopfenstein1@unl.edu \\ R. J. Cooper \\ Cattlemen's Nutrition Services, Lincoln, NE \\ See next page for additional authors
}

Follow this and additional works at: https://digitalcommons.unl.edu/animalscifacpub

Part of the Animal Sciences Commons

Griffin, W. A.; Erickson, G. E.; Dicke, B. D.; Klopfenstein, T. J.; Cooper, R. J.; Jordon, D. J.; Swingle, R. S.; Moseley, W. M.; Sides, G. E.; and Weigel, D. J., "Effects of Ractopamine (Optaflexx) Fed in Combination with Melengestrol Acetate on Feedlot Heifer Performance" (2009). Faculty Papers and Publications in Animal Science. 764.

https://digitalcommons.unl.edu/animalscifacpub/764

This Article is brought to you for free and open access by the Animal Science Department at DigitalCommons@University of Nebraska - Lincoln. It has been accepted for inclusion in Faculty Papers and Publications in Animal Science by an authorized administrator of DigitalCommons@University of Nebraska - Lincoln. 


\section{Authors}

W. A. Griffin, G. E. Erickson, B. D. Dicke, T. J. Klopfenstein, R. J. Cooper, D. J. Jordon, R. S. Swingle, W. M. Moseley, G. E. Sides, and D. J. Weigel 


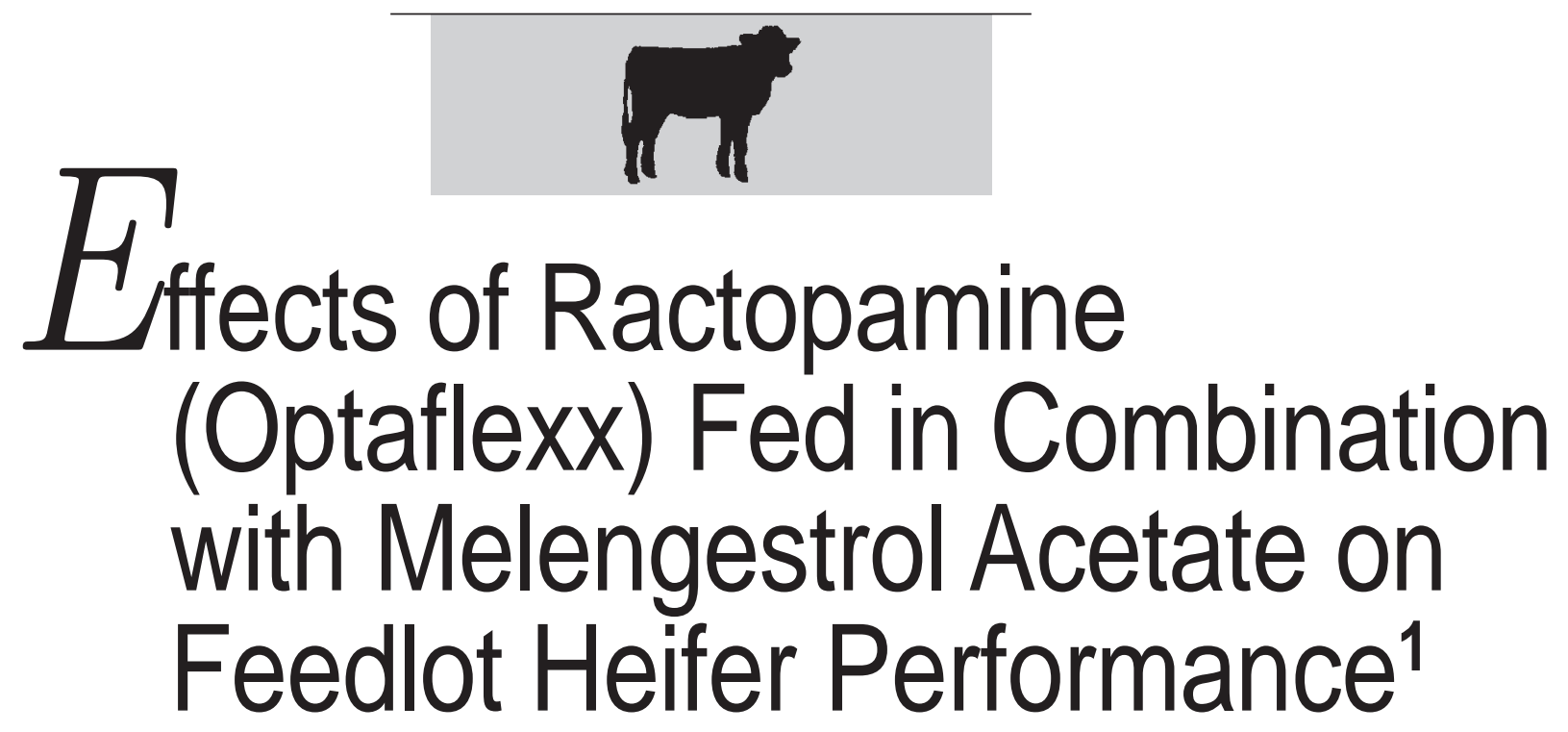

\begin{abstract}
W. A. Griffin,* ${ }^{*}$ G. E. Erickson, ${ }^{* 2}$ PAS, B. D. Dicke, $†$ PAS, T. J. Klopfenstein, ${ }^{*}$ R. J. Cooper, $\dagger$ D. J. Jordon, † R. S. Swingle,‡ W. M. Moseley,§ G. E. Sides,§ and D. J. Weigel§ *Department of Animal Science, University of Nebraska, Lincoln 68583-0908; †Cattlemen's Nutrition Services, Lincoln, NE 68516; ‡Cactus Feeders, Amarillo, TX 79116; and §Pfizer Inc., Kalamazoo, MI 49001
\end{abstract}

\begin{abstract}
Two commercial feedlot experiments were conducted to determine the effects of feeding melengestrol acetate (MGA) or MGA plus ractopamine ( $M G A+O P T)$ on the performance and carcass characteristics of finishing heifers. In Nebraska (Exp. 1), 1,807 heifers (337.3 \pm 20.0 $\mathrm{kg}$ ) and in Texas (Exp. 2), 1,964 heifers $(331.5 \pm 6.1 \mathrm{~kg})$ were fed $0.4 \mathrm{mg}$ of $M G A$ daily. For heifers fed $M G A+O P T$, $200 \mathrm{mg}$ of ractopamine was fed daily the last 29 (Exp. 2) or 36 d (Exp. 1). Live and carcass-adjusted performance data were collected. On a carcass-adjusted basis, G:F for the entire feeding period was improved $(P<0.01)$ by 1.7 and $3.7 \%$ in Exp. 1 and 2, respectively, for heifers fed $M G A+O P T$ compared with $M G A$. For the last 29 to $36 \mathrm{~d}, \mathrm{G}: F$ was increased $(P<0.02)$ by $8.1 \%$ (Exp. 1) or 27.2\% (Exp. 2) on a carcass-adjusted basis for heifers fed MGA+OPT compared with MGA. Fat thickness, USDA YG, marbling score, LM area, and percent-
\end{abstract}

\footnotetext{
${ }^{1}$ Published with the approval of the director as Journal Series No. 15089, Nebraska Agricultural Research Division.

${ }^{2}$ Corresponding author: geericks@unlnotes. unl.edu
}

age USDA Choice were not different ( $P$ $>0.47)$ between treatments in Exp. 1 . Carcasses from heifers fed $M G A+O P T$ had decreased marbling scores $(P=0.01)$ and greater $L M$ area $(P=0.01)$ than carcasses from heifers fed MGA in Exp. 2. In Exp. 1, in which G:F was improved by 8.1\%, no effect on $Q G$ was observed. In Exp. 2, in which G:F was improved by 27.2\%, QG decreased. Based on these results, feeding $M G A+O P T$ increased $A D G$ and improved $G: F$, with variable effects on carcass characteristics.

Key words: feedlot cattle, heifer, melengestrol acetate, Optaflexx, ractopamine

\section{INTRODUCTION}

Melengestrol acetate (Pfizer Animal Health, New York City, NY) is an easily administered, orally active progestogen that has been shown to increase BW gain and improve feed efficiency when compared with heifers that did not receive melengestrol acetate during the finishing period (Bloss et al., 1966; Lauderdale, 1983; Kreikemeier and Mader, 2004). Feeding melengestrol acetate inhibits estrus and ovulation and is a prod- uct commonly fed daily to finishing heifers at an inclusion level of 0.25 to $0.50 \mathrm{mg} /$ heifer. Carcass weights are the ultimate weight measure for determining the final value of a beef animal (Owens et al., 1993). $\beta$-Adrenergic agonists have been shown to cause changes in growth with increased accretion of skeletal muscle and decreased accretion of fat (Mersmann, 1998). Optaflexx (Elanco Animal Health, Greenfield, IN), the trade name for ractopamine- $\mathrm{HCl}$, is a $\beta-1$ adrenergic agonist. When Optaflexx was fed to heifers the last 28 to $42 \mathrm{~d}$ of the finishing period, heifers had increased weight gain on both a carcass-adjusted and BW basis, improved feed efficiency, and no change in marbling when fed at a rate of $10.0,20.0$, or $30.0 \mathrm{~g} /$ ton (Schroeder et al., 2003b). The increased BW and carcass weight were 7.2 and $2.9 \mathrm{~kg}$, respectively, for heifers fed $200 \mathrm{mg} /$ heifer daily. The BW response to feeding Optaflexx to heifers is less than the response in steers (Schroeder et al., 2003a,b; Laudert et al., 2004). These previous studies were completed before MGA was cleared to be fed with Optaflexx; therefore, diets did not include melengestrol acetate, nor 
did heifers receive implants containing trenbelone acetate. The objective of these experiments was to determine the effect of feeding Optaflexx in combination with melengestrol acetate on finishing heifer performance and carcass merit.

\section{MATERIALS AND METHODS}

\section{Experiment 1}

The experiment was conducted at a commercial feedlot in central Nebraska between August 2004 and March 2005 using 1,807 British $\times$ Continental heifers $(337.3 \mathrm{~kg} \pm 20.0)$ fed in 20 pens (10 pens/treatment). After arrival, heifers were individually weighed, processed, and blocked by date received and site of procurement. Therefore, within each replication, cattle were received on the same day and from the same point of origin in a balanced fashion. During initial processing, heifers were vaccinated for viral diseases (BoviShield Gold 4, Pfizer Animal Health), treated for internal and external parasites (Dectomax Injectable, Pfizer Animal Health), and implanted with Ralgro (SheringPlough Animal Health, Union, NJ). Heifers were determined to be bred, open, or freemartins by rectal palpation. Freemartins and heifers more than $100 \mathrm{~d}$ pregnant were removed from the trial. Heifers less than 100 $\mathrm{d}$ pregnant were given a single $5-\mathrm{mL}$ injection of Lutalyse (Pfizer Animal Health). Heifers diagnosed as open were not injected with Lutalyse. Therefore, if heifers were very early in pregnancy and unable to be identified as pregnant via rectal palpation, those heifers remained on trial. Heifers from separate locations were assigned randomly using processing order and by sorting every other heifer through the chute to 1 of 2 treatments. Heifers were then assigned randomly to their home pen (10 replications/treatment) with an average of 90 heifers/pen (range 60 to 145 heifers/pen). Treatments were 1) heifers fed melengestrol acetate for the entire finishing period (MGA), and 2) heifers fed melengestrol acetate for the entire finishing period and Optaflexx the last 31 to $38 \mathrm{~d}$ (MGA+OPT). Within each replication, heifers were monitored the same number of days during Optaflexx feeding in a balanced manner. Once initially processed, heifers were adapted to high-grain finishing diets; however, melengestrol acetate was not included during grain adaptation. The finishing diet was formulated to provide $0.4 \mathrm{mg} /$ heifer of melengestrol acetate, $330 \mathrm{mg} /$ heifer of Rumensin (Elanco Animal Health), and 90 $\mathrm{mg} /$ heifer of Tylan (Elanco Animal Health) daily. During the last 31 to 38 $\mathrm{d}$ of finishing (average of 35.5 across all 10 replications), Optaflexx was included in the diet to achieve a daily intake of $200 \mathrm{mg} /$ heifer for heifers fed the MGA+OPT treatment.

Heifers were reimplanted with Synovex Plus (Fort Dodge Animal Health, Overland Park, KS) an average of $80 \mathrm{~d}$ preslaughter (range 73 to $87 \mathrm{~d}$ ), with animals implanted on the same day within arrival block. The final diet contained $38 \%$ dry-rolled corn, $29.5 \%$ steam-flaked corn, $18 \%$ wet distillers grains plus solubles, $6 \%$ alfalfa hay, $2 \%$ sorghum hay, $1.5 \%$ fat, and $5 \%$ supplement in the control diet (DM basis). The MGA+OPT supplement was delivered in a pelleted form fed at $4 \%$ of the dietary DM to replace dry-rolled corn. The Optaflexx supplement consisted of finely ground corn and wheat middlings. Diet samples were taken once a month and analyzed at a commercial laboratory. The finishing diet contained $14.9 \%$ CP, $0.72 \% \mathrm{Ca}, 0.37 \% \mathrm{P}$, and $6.9 \%$ fat (DM basis). Heifers were fed an average of $133 \mathrm{~d}$ (range of 126 to 143 d balanced within each replication). Feed intake was calculated by using the amount of feed delivered to the bunk of each individual pen of cattle and corrected for DM of ingredients.

Performance was summarized on both a live BW basis as well as a carcass-adjusted basis. For live BW performance, pen BW were taken for each pen at initial processing, reimplantation, the beginning of Optaflexx feeding, and before shipment on the day of slaughter. Pen weights were shrunk 4\%. Initial pen BW were not shrunk because animals were processed immediately upon arrival or after an overnight receiving period. Pen weights were used for performance calculations on a live BW basis. Carcass weights were adjusted to a common dressing percentage of $63.5 \%$ to calculate a carcass-adjusted final BW. The constant dressing percentage of $63.5 \%$ was used in both experiments to reduce the variation in BW measures that can occur from factors such as gut fill (MacDonald et al., 2007). Carcass-adjusted final BW was used to determine ADG and G:F on a carcass-adjusted basis.

Both pens within a block (replication) were harvested under similar conditions on the same day at the same plant. Hot carcass weights $(\mathbf{H C W})$ and liver abscesses were recorded on the day of slaughter. Carcass fat thickness, USDA called marbling score, KPH, LM area, and USDA YG were recorded after a 24 - to 36 -h chill. Yield grade was calculated as $2.5+(6.35 \times$ fat thickness, $\mathrm{cm})+(0.0017 \times$ HCW, $\mathrm{kg})+$ $(0.2 \times \mathrm{KPH}, \%)-(2.06 \times \mathrm{LM}$ area, $\mathrm{cm}^{2}$ ), from Boggs and Merkel (1993). Empty body fat was calculated as $17.76207+(4.68142 \times$ rib fat thickness, $\mathrm{cm})+(0.01945 \times \mathrm{HCW}, \mathrm{kg})+$ (0.81855× marbling/100) - $(0.06754$ $\times$ LM area, $\mathrm{cm}^{2}$ ), from (Guiroy et al., 2002).

\section{Experiment 2}

This experiment was conducted at a commercial feedlot located in the Texas Panhandle between October 2004 and February 2005 using 1,964 $(331.5 \mathrm{~kg} \pm 6.1)$ British $\times$ Continental heifers fed in 20 pens (10 pens/ treatment). After arrival, heifers were individually weighed, processed, and blocked by date received and site of procurement. During initial processing, heifers were vaccinated for viral diseases (BoviShield Gold 4 and Fortress 7, Pfizer Animal Health), treated for internal and external parasites (Dectomax Injectable, Pfizer Animal Health), and given a single Revalor $\mathrm{H}$ implant (Intervet Inc., Millsboro, DE) at arrival. Heifers were determined to 
be bred, open, or freemartins by rectal palpation. Freemartins and heifers more than $100 \mathrm{~d}$ bred were removed from the trial. Heifers determined to be less than $100 \mathrm{~d}$ bred were given a single 5-mL injection of Lutalyse. Heifers diagnosed as open were not injected with Lutalyse, which, similar to Exp. 1, allowed some heifers in early pregnancy to complete the trial. Heifers were allocated to 1 of 2 treatments by gate-sorting groups of 2 . Heifers were then assigned to 1 of 20 home pens (10 replications/treatment) with an average of 98 heifers/pen (range 84 to 107). Treatments were identical to Exp. 1, with heifers fed either melengestrol acetate (MGA) for the entire finishing period or fed MGA for the entire finishing period and Optaflexx the last $29 \mathrm{~d}$ (range 28 to 29 d; MGA+OPT). The finishing diet was formulated to provide 0.4 $\mathrm{mg} /$ heifer of MGA, $330 \mathrm{mg} /$ heifer of Rumensin, and $90 \mathrm{mg} /$ heifer Tylan daily. The Optaflexx was included in the diet to provide $200 \mathrm{mg} /$ heifer daily for heifers fed the MGA+OPT treatment. Heifers were fed a finishing diet containing $74.1 \%$ steam-flaked corn, $7.5 \%$ dried distillers grains, $6.6 \%$ corn silage, $4.8 \%$ alfalfa hay, $3.0 \%$ tallow, and $4.0 \%$ supplement (DM basis). Feed additives (MGA, Rumensin, and Tylan) were added to the diet with a micro-weigh machine in the feedmill (Micro Beef Technologies, Amarillo, TX). The Optaflexx

\section{Table 1. Live performance and carcass-adjusted performance for finishing heifers fed melengestrol acetate or melegestrol acetate plus Optaflexx in Exp. 1}

\begin{tabular}{lcccc} 
Item & MGA $^{1}$ & MGA+OPT $^{2}$ & SEM & $P$-value \\
\hline Live performance & & & & \\
Initial BW, kg & 337.1 & 336.2 & 6.3 & 0.77 \\
Reimplant BW, kg & 448.6 & 447.2 & 8.6 & 0.88 \\
Start of Optaflexx BW, kg & 523.2 & 525.5 & 7.5 & 0.73 \\
Final BW, kg & 570.4 & 577.4 & 7.8 & 0.53 \\
Overall & & & & \\
DMI, kg/d & & 10.78 & 0.21 & $<0.01$ \\
ADG, kg/d & 10.61 & 1.81 & 0.05 & 0.41 \\
G:F & 1.75 & 0.168 & 0.003 & 0.03 \\
Last 35.5 d & 0.165 & & & \\
DMI, kg/d & & 10.67 & 0.13 & 0.01 \\
Total BW gain, kg & 10.37 & 51.9 & 1.96 & 0.09 \\
ADG, kg/d & 47.2 & 1.48 & 0.06 & 0.09 \\
G:F & 1.35 & 0.137 & 0.004 & 0.07 \\
Carcass-adjusted performance ${ }^{5}$ & 0.128 & & & \\
Final BW, kg & 573.2 & 580.5 & 7.5 & $<0.01$ \\
Overall & & & & \\
ADG, kg/d & 1.88 & 1.94 & 0.05 & $<0.01$ \\
G:F & 0.177 & 0.180 & 0.001 & $<0.01$ \\
Last 35.5 d & & & & \\
Total BW gain, kg & 50.1 & 55.1 & 2.5 & 0.02 \\
ADG, kg/d & 1.41 & 1.56 & 0.07 & 0.01 \\
G:F & 0.136 & 0.146 & 0.007 & 0.02 \\
\hline
\end{tabular}

${ }^{1} \mathrm{MGA}=$ treatment in which melengestrol acetate (Pfizer Animal Health, New York City, NY) was administered alone for the entire feeding period.

${ }^{2} \mathrm{MGA}+\mathrm{OPT}=$ treatment in which melengestrol acetate was administered for the entire feeding period and Optaflexx (Elanco Animal Health, Greenfield, IN) was included in the ration for the last $35.5 \mathrm{~d}$ of the finishing period.

${ }^{3}$ Heifer performance over the entire finishing period.

${ }^{4}$ Heifer performance during inclusion of Optaflexx in diet for the last $35.5 \mathrm{~d}$ before slaughter.

${ }^{5}$ Carcass-adjusted performance is hot carcass weight/0.635.

was hand-weighed and added to the treatment diet using a water flush and was mixed on the feed truck at each feeding. Diets were tested once a month and analyzed at a commercial laboratory. The finishing diet contained $13.6 \% \mathrm{CP}, 0.56 \% \mathrm{Ca}, 0.32 \%$ $\mathrm{P}$, and $7.48 \%$ fat (DM basis). Heifers were fed an average of 138 d (range of 135 to $140 \mathrm{~d}$, balanced within each replication).

Pen BW were taken for each pen at initial processing, at the beginning of Optaflexx feeding, and before shipment on the day of slaughter. Pen BW were shrunk 4\% except for initial pen BW because animals were processed immediately upon arrival. Pen BW were used for performance calculations on a BW basis. Carcass weights were adjusted to a common dressing percentage of $63.5 \%$ to calculate a carcass-adjusted final BW. Carcass-adjusted final BW was used to determine ADG and G:F on a carcass-adjusted basis.

All pens in this experiment were harvested on the same day at the same abattoir. Hot carcass weights and liver abscesses were recorded on the day of harvest. Carcass fat thickness, USDA called marbling score, KPH, LM area, and USDA YG were recorded after a 24 -h chill. Yield grade and empty body fat were calculated as defined for Exp. 1.

\section{Statistical Analysis}

Experiments 1 and 2 were analyzed as a randomized block design. Animal performance and carcass data were analyzed using the MIXED procedure (SAS Inst. Inc., Cary, NC), with treatment as a fixed effect and block as a random effect. In this study, pen was used as the experimental unit. The USDA marbling score and calculated YG were analyzed using a chi-square analysis. Data are presented with dead animals and railers removed from the analysis. 
Table 2. Carcass characteristics for finishing heifers fed melengestrol acetate or melengestrol acetate plus Optaflexx in Exp. 1

\begin{tabular}{|c|c|c|c|c|}
\hline Item & MGA $^{1}$ & MGA+OPT ${ }^{2}$ & SEM & $P$-value \\
\hline Hot carcass weight, kg & 364.7 & 368.0 & 1.7 & 0.02 \\
\hline Fat thickness, cm & 1.43 & 1.42 & 0.04 & 0.62 \\
\hline$Y_{G^{3}}$ & 2.74 & 2.76 & 0.10 & 0.72 \\
\hline YG 1, \% & 19.1 & 17.1 & - & - \\
\hline YG 2, \% & 44.7 & 45.7 & - & - \\
\hline YG 3, \% & 29.9 & 31.1 & - & - \\
\hline YG 4, \% & 5.5 & 5.5 & - & - \\
\hline YG $5, \%$ & 0.7 & 0.6 & - & - \\
\hline Marbling ${ }^{4}$ & 553.6 & 551.7 & 6.1 & 0.72 \\
\hline Prime, \% & 1.2 & 1.2 & - & - \\
\hline Choice $^{+}, \%$ & 4.9 & 6.5 & - & - \\
\hline Choice $^{0}, \%$ & 20.0 & 17.4 & - & - \\
\hline Choice $^{-}, \%$ & 45.8 & 46.4 & - & - \\
\hline Select, $\%$ & 27.1 & 27.5 & - & - \\
\hline Standard, \% & 0.9 & 1.0 & - & - \\
\hline LM area, $\mathrm{cm}^{2}$ & 92.95 & 92.82 & 1.39 & 0.88 \\
\hline $\mathrm{KPH}, \%$ & 1.96 & 1.95 & 0.01 & 0.24 \\
\hline Dressing percentage, \% & 63.82 & 63.85 & 0.22 & 0.87 \\
\hline Empty body fat, ${ }^{5} \%$ & 29.75 & 29.74 & 0.25 & 0.96 \\
\hline
\end{tabular}

${ }^{1} \mathrm{MGA}=$ treatment in which melengestrol acetate (Pfizer Animal Health, New York City, NY) was administered alone for the entire feeding period.

${ }^{2} \mathrm{MGA}+\mathrm{OPT}=$ treatment in which melengestrol acetate was administered for the entire feeding period and Optaflexx (Elanco Animal Health, Greenfield, IN) was included in the ration for the last $35.5 \mathrm{~d}$ of the finishing period.

${ }^{3} Y G=2.5+(6.35 \times$ fat thickness, $\mathrm{cm})+(0.0017 \times$ hot carcass weight, $\mathrm{kg})+(0.2 \times$ $\mathrm{KPH}, \%)-(2.06 \times$ LM area); from Boggs and Merkel (1993).

${ }^{4}$ Marbling $=400=$ Slight $^{0}, 500=$ Small $^{0}$, and so on.

${ }^{5}$ Empty body fat $=17.76207+(4.68142 \times$ rib fat thickness, $\mathrm{cm})+(0.01945 \times$ hot carcass weight, $\mathrm{kg})+(0.81855 \times$ marbling/100 $)-\left(0.06754 \times \mathrm{LM}\right.$ area, $\left.\mathrm{cm}^{2}\right)$; from Guiroy et al. (2002).

\section{RESULTS AND DISCUSSION}

\section{Experiment 1}

Fifteen animals (8 MGA+OPT and 7 MGA) were removed from the study before slaughter. Four and 3 heifers were removed from the MGA+OPT and MGA treatments, respectively, after inclusion of Optaflexx. Data were not collected from 72 rail-outs in the plant (46 MGA and $26 \mathrm{MGA}+\mathrm{OPT}$ heifers). Of the 1,720 heifers harvested, 852 were fed MGA and 868 were fed MGA+OPT. Fetuses were observed at slaughter in 82 heifers: 39 in the MGA treatment and 43 in the MGA+OPT treatment. These pregnant heifers were included in the final analysis because we observed approximately the same number of heifers in each treatment, and there was no $\mathrm{kg}$ or $1.2 \%$ in heifers fed MGA+OPT. Dry matter intake was increased by $0.17 \mathrm{~kg} / \mathrm{d}(P<0.01)$ for heifers fed MGA+OPT compared with heifers fed MGA alone over the entire feeding period. Feed efficiency was improved 1.8\% $(P=0.03)$ for heifers fed MGA+OPT compared with heifers fed MGA, even though ADG was not affected $(P=0.41)$ when comparing treatments over the entire 133 -d finishing period on a live BW basis.

When comparing treatments during the last $35.5 \mathrm{~d}$ (the time heifers were fed Optaflexx), heifers receiving MGA+OPT were numerically heavier $(525.5$ vs. $523.2 \mathrm{~kg})$ at the beginning of the period. Given this 2.3-kg advantage in initial BW for heifers fed $\mathrm{MGA}+\mathrm{OPT}$, the BW gain increase for heifers assigned to MGA+OPT was $4.7 \mathrm{~kg}$, an improvement in BW gain of $10.2 \%(P=0.09)$ compared with heifers fed MGA. Dry matter intake was increased $(P=0.01)$ by $0.30 \mathrm{~kg} /$ heifer. Feeding MGA+OPT increased ADG (live basis) by 0.13 $\mathrm{kg} / \mathrm{d}(P=0.09)$, which led to a $7.0 \%$ improvement $(P=0.07)$ in feed efficiency compared with heifers receiving MGA.

On a carcass-adjusted basis (HCW/0.635), final BW was increased $(P=0.01)$ by $7.3 \mathrm{~kg}$ or $1.3 \%$ for heifers receiving MGA+OPT compared with heifers fed MGA. When ADG was calculated from carcass weight, heifer ADG was increased $(P$ $<0.01)$ by $0.06 \mathrm{~kg} /$ heifer, with an improvement $(P<0.01)$ in feed efficiency of $1.7 \%$ for heifers over the entire feeding period. Despite the relatively small improvement when expressed over the entire feeding period, ADG and G:F of heifers fed MGA+OPT compared with heifers fed MGA on a carcass-adjusted basis were significantly different. When looking at only the last $35.5 \mathrm{~d}$ of performance, MGA+OPT heifers gained $0.15 \mathrm{~kg} / \mathrm{d}$ more $(P=0.01)$, and G:F improved by $8.1 \%(P=0.02)$ compared with heifers receiving MGA.

Carcasses of heifers in the MGA+OPT treatment groups (Table 2) did not differ in USDA YG, marbling score, percentage of USDA 
choice and select based on chi-square analysis, fat thickness, LM area, $\mathrm{KPH}$, empty body fat, cutability, and dressing percentage when compared with heifers fed MGA. However, heifers fed MGA+OPT had $3.3 \mathrm{~kg}$ heavier $(0.9 \%) \mathrm{HCW}(P<0.01)$.

\section{Experiment 2}

Forty-nine heifers (22 MGA+OPT and 27 MGA) were removed from the study before slaughter. One and 2 heifers were removed from the MGA and the MGA+OPT treatment, respectively, after inclusion of Optaflexx. Of the 1,915 heifers harvested, 957 were fed MGA and 958 were fed MGA+OPT. Fetuses were observed in 56 heifers at slaughter: 22 in the MGA treatment and 34 in the MGA+OPT group. These pregnant heifers were included in the final analysis for the same reasons as in Exp. 1.

In this study, the MGA+OPT diet was formulated to achieve $200 \mathrm{mg} /$ heifer daily. Based on the method (micro-weigh machine) in which Optaflexx was delivered to the bunk, DMI differences (range 8.3 to $9.4 \mathrm{~kg}$ ) across block had no effect on actual Optaflexx intake. Therefore, daily intake of Optaflexx averaged $200 \mathrm{mg}$ /heifer. Animals consumed an average of $0.384 \mathrm{mg} / \mathrm{kg}$ Optaflexx (range 0.366 to $0.396 \mathrm{mg} / \mathrm{kg}$ ) when calculated on a per kilogram of BW basis.

\section{Table 3. Live performance and carcass-adjusted performance for finishing heifers fed melengestrol acetate or melegestrol acetate plus Optaflexx in Exp. 2}

\begin{tabular}{lcccr} 
Item & MGA $^{1}$ & MGA+OPT $^{2}$ & SEM & $P$-value \\
\hline $\begin{array}{l}\text { Live performance } \\
\text { Initial BW, kg }\end{array}$ & & & & \\
Start of Optaflexx BW, kg & 331.9 & 329.7 & 2.0 & 0.09 \\
Final BW, kg & 505.4 & 501.8 & 3.6 & 0.43 \\
Overall & & & & \\
DMI, kg/d & 534.9 & 539.0 & & 0.35 \\
ADG, kg/d & & & & \\
G:F & 8.98 & 8.97 & 0.12 & 0.95 \\
Last 29 d4 & 1.47 & 1.52 & 0.02 & 0.10 \\
DMI, kg/d & 0.163 & 0.169 & 0.002 & $<0.01$ \\
Total BW gain, kg & & & & \\
ADG, kg/d & 8.82 & 8.81 & 0.10 & 0.94 \\
G:F & 29.5 & 37.2 & 1.4 & $<0.01$ \\
Carcass-adjusted performance ${ }^{5}$ & 1.02 & 1.28 & 0.05 & $<0.01$ \\
Final BW, kg & 0.113 & 0.143 & 0.005 & $<0.01$ \\
Overall & & & & \\
ADG, kg/d & 534.6 & 539.7 & 2.2 & 0.19 \\
G:F & & & & \\
Last 29 d & 1.47 & 1.52 & 0.02 & 0.04 \\
Total BW gain, kg & 0.163 & 0.169 & 0.002 & $<0.01$ \\
ADG, kg/d & & & & \\
G:F & 29.2 & 37.9 & 1.5 & $<0.01$ \\
\hline
\end{tabular}

${ }^{1} \mathrm{MGA}=$ treatment in which melengestrol acetate (Pfizer Animal Health, New York City, NY) was administered alone for the entire feeding period.

${ }^{2} \mathrm{MGA}+\mathrm{OPT}=$ treatment in which melengestrol acetate was administered for the entire feeding period and Optaflexx (Elanco Animal Health, Greenfield, IN) was included in the ration for the last $29 \mathrm{~d}$ of the finishing period.

${ }^{3}$ Heifer performance over the entire finishing period.

${ }^{4}$ Heifer performance during inclusion of Optaflexx in diet for the last $29 \mathrm{~d}$ before slaughter.

${ }^{5}$ Carcass-adjusted performance is hot carcass weight/0.635.
Heifer live and carcass-adjusted performance results are presented in Table 3. Final live BW was not different $(P=0.35)$ between treatments, although heifers receiving $\mathrm{MGA}+\mathrm{OPT}$ were $4.1 \mathrm{~kg}(0.8 \%)$ heavier than animals receiving MGA. Total BW gain during Optaflexx feeding was greater $(P<0.01)$ for heifers receiving $\mathrm{MGA}+\mathrm{OPT}$ compared with heifers receiving MGA. The DMI was not affected by feeding Optaflexx $(P$ $=0.95$ ) over the entire feeding period. Average daily gain was not statistically different $(P=0.10)$, but showed a numerical increase of $0.05 \mathrm{~kg} / \mathrm{d}$ for heifers fed MGA+OPT compared with heifers fed MGA. Feed efficiency was improved by $3.7 \%$ when Optaflexx was included in the diet of heifers receiving MGA $(P<0.01)$, even though DMI and ADG were only slightly affected over the entire 138-d feeding period.

Over the last $29 \mathrm{~d}$ on feed (the time heifers were receiving Optaflexx), DMI was not influenced $(P=0.94)$ by treatment. Final BW minus BW at the beginning of Optaflexx feeding exhibited a $7.7-\mathrm{kg}(P<0.01)$ improvement in BW gain in $\mathrm{MGA}+\mathrm{OPT}$ compared with heifers fed MGA. Feeding MGA+OPT increased ADG $0.26 \mathrm{~kg} / \mathrm{d}(25.5 \%)$ when compared with heifers receiving MGA $(P<$ 0.01). Increased ADG, without a change in DMI, caused heifers receiving MGA+OPT to be $26.5 \%$ more efficient $(P<0.01)$ compared with heifers receiving MGA.

Carcass-adjusted live performance (HCW/0.635) over the entire feeding period indicated heifers receiving MGA+OPT had a $5.1 \mathrm{~kg}$ heavier adjusted final BW $(P=0.19)$. Because of the difference in heifer BW at the initiation of Optaflexx, BW gained over the last 29-d period was $37.9 \mathrm{~kg}$ for MGA+OPT compared with 29.2 $\mathrm{kg}$ for heifers receiving MGA, an 8.7$\mathrm{kg}$ difference $(P<0.01)$. Heifers receiving MGA+OPT gained $0.05 \mathrm{~kg} / \mathrm{d}$ (3.4\%) more $(P=0.04)$ when compared with heifers receiving MGA. Feed efficiency was also improved by $3.7 \%(P<0.01)$ for heifers receiving MGA+OPT. During the last 29 
$\mathrm{d}$ of the feeding period, heifers fed MGA+OPT gained $0.30 \mathrm{~kg} / \mathrm{d}$ more $(P<0.01)$, a $30.3 \%$ improvement, and exhibited an improvement in G:F of $27.2 \%(P<0.01)$ over MGA heifers.

Carcasses of heifers fed MGA+OPT were $3.2 \mathrm{~kg}$ heavier than those from heifers fed MGA (Table 4). However, because of the difference in $\mathrm{BW}$ at the beginning of Optaflexx feeding, initial BW at the beginning of Optaflexx feeding $(\mathrm{BW} \times 0.635$ subtracted from the HCW) was used to determine the amount of carcass weight gained in the last $29 \mathrm{~d}$ of the feeding period. With this approach, heifers receiving MGA+OPT gained $24.1 \mathrm{~kg}$ of carcass weight compared with $18.6 \mathrm{~kg}$ for heifers receiving MGA. Assuming that differences in live BW are real, heifers receiv- ing Optaflexx actually gained $5.5 \mathrm{~kg}$ more (instead of $3.4 \mathrm{~kg}$ ) than heifers receiving MGA. When other carcass characteristics were compared, no significant differences were observed between MGA and MGA+OPT for fat thickness, KPH fat, dressing percentage, empty body fat, or cutability. Carcasses of heifers fed MGA+OPT had reduced marbling scores $(P=$ $0.01)$ and $2.37 \mathrm{~cm}^{2}$ greater LM area $(P=0.01)$ and tended to exhibit reduced YG (2.48 vs. $2.59 ; P=0.11$ ) compared with carcasses from heifers fed MGA. Carcasses from heifers receiving MGA+OPT graded $59.9 \%$ Low Choice or better compared with $71.4 \%$ for heifers receiving MGA ( $P$ $=0.05)$.

Previous research by Laudert et al. (2004) and Schroeder et al. (2003a) showed steers receiving Optaflexx

\section{Table 4. Carcass characteristics for finishing heifers fed melengestrol acetate or melengestrol acetate plus Optaflexx in Exp. 2}

\begin{tabular}{|c|c|c|c|c|}
\hline Item & $\mathrm{MGA}^{1}$ & MGA+OPT ${ }^{2}$ & SEM & $P$-value \\
\hline Hot carcass weight, kg & 339.5 & 342.7 & 2.2 & 0.19 \\
\hline Fat thickness, cm & 1.36 & 1.35 & 0.05 & 0.72 \\
\hline$Y G^{3}$ & 2.59 & 2.48 & 0.07 & 0.11 \\
\hline YG 1, \% & 24.8 & 28.5 & - & - \\
\hline YG 2, \% & 43.5 & 47.6 & - & - \\
\hline YG 3, \% & 27.0 & 19.1 & - & - \\
\hline YG 4, \% & 4.5 & 4.4 & - & - \\
\hline YG 5, \% & 0.2 & 0.4 & - & - \\
\hline Marbling ${ }^{4}$ & 534.0 & 519.4 & 7.1 & 0.01 \\
\hline Prime, \% & 0.9 & 1.5 & - & - \\
\hline Choice $^{+}, \%$ & 0.8 & 0.5 & - & - \\
\hline Choice $^{0}, \%$ & 11.7 & 8.5 & - & - \\
\hline Choice $^{-}, \%$ & 58.0 & 49.4 & - & - \\
\hline Select, \% & 28.3 & 39.5 & - & - \\
\hline Standard, \% & 0.3 & 0.6 & - & - \\
\hline LM area, $\mathrm{cm}^{2}$ & 90.24 & 92.61 & 0.72 & 0.01 \\
\hline $\mathrm{KPH}, \%$ & 1.88 & 1.86 & 0.01 & 0.36 \\
\hline Dressing percentage, \% & 63.47 & 63.58 & 0.09 & 0.39 \\
\hline Empty body fat, ${ }^{5} \%$ & 28.18 & 27.89 & 0.31 & 0.27 \\
\hline
\end{tabular}

${ }^{1} \mathrm{MGA}=$ treatment in which melengestrol acetate (Pfizer Animal Health, New York City, NY) was administered alone for the entire feeding period.

${ }^{2} \mathrm{MGA}+\mathrm{OPT}=$ treatment in which melengestrol acetate was administered for the entire feeding period and Optaflexx (Elanco Animal Health, Greenfield, IN) was included in the ration for the last $29 \mathrm{~d}$ of the finishing period.

${ }^{3} Y G=2.5+(6.35 \times$ fat thickness, $\mathrm{cm})+(0.0017 \times$ hot carcass weight, $\mathrm{kg})+(0.2 \times$ $\mathrm{KPH}, \%)-(2.06 \times$ LM area); from Boggs and Merkel (1993).

${ }^{4}$ Marbling $=400=$ Slight $^{0}, 500=$ Small $^{0}$, etc.

${ }^{5}$ Empty body fat $=17.76207+(4.68142 \times$ rib fat thickness, $\mathrm{cm})+(0.01945 \times$ hot carcass weight, $\mathrm{kg})+(0.81855 \times$ marbling $/ 100)-\left(0.06754 \times \mathrm{LM}\right.$ area, $\left.\mathrm{cm}^{2}\right)$; from Guiroy et al. (2002). gained, respectively, 6.7 and $7.2 \mathrm{~kg}$ of BW more compared with control steers. Carcass weight was also increased by 5.6 and $6.4 \mathrm{~kg}$ compared with control steers. Similar responses were observed by Abney et al. (2007), in which final BW, ADG, and G:F increased linearly as the Optaflexx dose increased from 0 to $200 \mathrm{mg}$ of Optaflexx daily. Final BW increased by $9.4 \mathrm{~kg}$ and carcass weight increased by $6.9 \mathrm{~kg}$ for steers fed $200 \mathrm{mg}$ of Optaflexx for either 28,35 , or $42 \mathrm{~d}$ compared with no Optaflexx (Abney et al., 2007). These authors did not observe an interaction between length of feeding and dose. Winterholler et al. (2007) observed an 11-kg increase in final BW and an 8-kg increase in HCW for steers fed $200 \mathrm{mg}$ of Optaflexx daily for $28 \mathrm{~d}$ in a commercial study.

However, with heifers, Schroeder et al. (2003b) found that those fed Optaflexx were $6.6 \mathrm{~kg}$ heavier (live BW basis) and had 2.9-kg heavier carcasses compared with heifers not fed Optaflexx. At the time of their heifer research, Optaflexx was not approved to be fed with melengestrol acetate. Therefore, melengestrol acetate was not included in the diet and heifers were not implanted with trenbelone acetate. In the current study, live $\mathrm{BW}$ and carcass gain responses to Optaflexx with melengestrol acetate feeding were greater than previously observed for heifers not fed melengestrol acetate. Responses of the current study are more comparable with those observed in steers and in more recent heifer studies. Walker et al. (2006) individually fed 72 heifers 0 or $200 \mathrm{mg}$ Optaflexx with melengestrol acetate included and observed a $6.9-\mathrm{kg}$ increase in HCW when averaged across different protein treatments (with no interaction observed). In their study, ADG and G:F were increased by approximately $25 \%$ and were significant when using carcass-adjusted performance.

Quinn et al. (2008) fed approximately 300 heifers either 0 or 200 mg of Optaflexx and observed an improvement of only $9.6 \%$ in G:F in their first experiment, with no signifi- 
cant differences in BW or HCW. In their second experiment, their treatment design was unique in that they fed Optaflexx at a rate of $200 \mathrm{mg}$ for 28 or 42 d, fed Optaflexx at a rate of $300 \mathrm{mg}$ for $28 \mathrm{~d}$, or fed a treatment that had increasing amounts of Optaflexx across $42 \mathrm{~d}$ (100 mg, then $200 \mathrm{mg}$, followed by $300 \mathrm{mg}$ ) and observed that heifers fed Optaflexx had a 3 - to 8 -kg increase in $\mathrm{HCW}$ across the different Optaflexx treatments (Quinn et al., 2008). Although the different treatments containing Optaflexx were not different from each other, the heifers fed $200 \mathrm{mg}$ for $42 \mathrm{~d}$ had the numerically greatest increase in $\mathrm{HCW}$. In our study, heifers fed Optaflexx for 29 d (Exp. 2) had a much greater response in ADG and $\mathrm{G}: \mathrm{F}$ than heifers fed for an average of 36 d (Exp. 1).

In previous Optaflexx studies (Schroeder et al., 2003a), DMI was not affected by treatment, and similar results were observed in Exp. 2. However, in Exp. 1, DMI was slightly greater for heifers fed MGA+OPT compared with heifers fed MGA. Many experiments have observed no change in DMI (Abney et al., 2007; Sissom et al., 2007; Winterholler et al., 2007).

Previous research (Schroeder et al., 2003b) showed heifers fed Optaflexx alone demonstrated a 17.5\% improvement $(P<0.03)$ in $\mathrm{ADG}$ when compared with control heifers and a $14.0 \%$ improvement in $\mathrm{G}: \mathrm{F}$ ( $P$ $<0.03$ ) during a 28- to 42-d feeding period. In Exp. 1, ADG was improved by $10.6 \%$ and $\mathrm{G}: \mathrm{F}$ was improved by 8.1\% when Optaflexx was fed. In Exp. 2, ADG increased 30.3\%, with a $27.2 \%$ improvement in G:F for heifers fed MGA+OPT compared with heifers fed MGA. The results from Exp. 1 were not as great as the improvement shown by Schroeder et al. (2003b). In Exp. 2, however, heifers fed MGA+OPT performed better than heifers fed Optaflexx with no melengestrol acetate (Schroeder et al., 2003b).

When evaluating the entire feeding period with shrunk initial BW and $\mathrm{HCW}$ to avoid possible errors in BW measurement, the response to feeding MGA+OPT compared with MGA was 3.2 and $3.4 \%$ for Exp. 1 and Exp. 2, respectively. However, G:F was increased by 1.7 and $3.7 \%$ by feeding MGA+OPT compared with MGA for Exp. 1 and Exp. 2, respectively. Sissom et al. (2007) evaluated Optaflexx fed at $200 \mathrm{mg}$ for $28 \mathrm{~d}$ in 2 commercial experiments with all feedlot heifers fed melengestrol acetate. Their first experiment evaluated 2 implant regimens factorialized with Optaflexx (0 or $200 \mathrm{mg}$ ), and no interactions between implant regimen and Optaflexx feeding were observed. Over the 182-d feeding period, ADG was increased $2.2 \%$ and G:F was increased by $3.9 \%$ (Sissom et al., 2007). In their second experiment, heifers were fed for a total of 129, 150, or $170 \mathrm{~d}$ and no interaction between Optaflexx treatment and days on feed were observed. The only significant response was observed for $\mathrm{G}: \mathrm{F}$, which increased $2.4 \%$ because of Optaflexx (Sissom et al., 2007).

Schroeder et al. (2003b) found that feeding Optaflexx had no effect on fat thickness, KPH, LM area, YG, or marbling. No carcass quality changes were observed between heifers fed MGA or MGA+OPT in Exp. 1. However, there was an increase in LM area and a significant decrease in marbling score in Exp. 2. When comparing USDA QG, Exp. 1 showed no difference between treatments for percent Choice carcasses. In Exp. 2, there was a difference in carcass QG, with less USDA Choice carcasses for heifers fed MGA+OPT vs. MGA (59.9 vs. $71.4 \%$, respectively).

Heifers were implanted differently between Exp. 1 and Exp. 2. Heifers in Exp. 1 received a mild estrogen implant upon arrival and were reimplanted with a strong combination implant. Heifers in Exp. 2 were implanted once at arrival with a moderate combination implant. Implants have been shown to decrease the QG of cattle (Crouse et al., 1987; Simms et al., 1988) when comparisons are made with similar days on feed and not at the same empty body fat or composition. When implant programs were compared at equal empty body fat, carcass quality appeared to be unaffected (Guiroy et al., 2002). There was no difference between marbling scores when comparing implant programs that used a mild combination or a strong combination implant program (Morgan, 1997). In Exp. 1, with an aggressive implant program, there was no difference in carcass quality caused by Optaflexx feeding; however, in Exp. 2, with a less aggressive implant in heifers fed MGA+OPT, carcass quality was decreased compared with feeding MGA. These data suggest that an aggressive implant program can be used in heifers receiving MGA+OPT without affecting carcass quality. This conclusion is further supported by Sissom et al. (2007), who did not observe an interaction between implant treatments and Optaflexx feeding. Clearly, previous research with steers representing different genotypes and implant programs suggests that the influence of Optaflexx on carcass quality characteristics is consistent in terms of carcass quality (Schroeder et al., 2003a; Gruber et al., 2007).

In Exp. 2, heifers receiving MGA+OPT had an empty body fat percentage that was 0.29 percentage units less than heifers receiving MGA $(P=0.27)$. Although not significant, this difference in empty body fat may suggest that heifers were at different body compositions between these 2 treatments before Optaflexx feeding, or that body composition was influenced by Optaflexx feeding. Because no effect of feeding Optaflexx was observed on body composition in Exp. 1, and in previous heifer studies (Schroeder et al., 2003b), body composition may have been different between heifers on each treatment before initiation of Optaflexx feeding. It is unclear what other factors may have led to different carcass quality responses between treatments in Exp. 1 and 2. Previous research with feeding Optaflexx to heifers suggests no effect on marbling (Walker et al., 2006; Sissom et al., 2007; Quinn et al., 2008); however, these studies have observed variable impacts of feeding 
Optaflexx to heifers in terms of LM area and fat depth.

Previous research suggests that providing Optaflexx to heifers at inclusion amounts greater than $200 \mathrm{mg}$ can lead to decreases in marbling score (Schroeder et al., 2003b), whereas ADG and G:F are improved. However, in previous studies, Optaflexx fed at rates of $200 \mathrm{mg}$ or less per day did not negatively affect carcass quality. Heifers consumed 205.0 and $200.0 \mathrm{mg} /$ heifer daily in Exp.1 and 2, respectively, suggesting that carcass quality should not be negatively affected. Optaflexx intakes, expressed as milligrams of intake per kilogram of BW, were 0.371 and 0.384, respectively, for Exp. 1 and 2. Although this difference is small between Exp. 1 and 2, Optaflexx intake (on a $\mathrm{mg} / \mathrm{kg}$ BW basis) may partially explain the difference in ADG and G:F responses between experiments.

Based on results from these 2 experiments and previous research with heifers, the response to MGA+OPT consistently improved ADG and G:F. The most difficult response to quantify consistently across these experiments appeared to be the absolute BW response to feeding Optaflexx to heifers. This was likely due to difficulty in obtaining accurate BW measurements, especially late in the feeding period. However, based on these 2 experiments and recent research with heifers fed Optaflexx, the observed increase in HCW attributable to Optaflexx suggests the BW response was greater for Optaflexx when fed in combination with melengestrol acetate than in early studies in which melengestrol acetate was not fed with Optaflexx. Interestingly, when the BW response was less within these 2 experiments, no quality differences were observed (i.e., in Exp. 1). When the BW response was large in Exp. 2, then marbling score was slightly reduced; therefore, the effects on degree of marbling may be influenced by the magnitude of the BW response.

\section{IMPLICATIONS}

These data suggest that feeding Optaflexx at $200 \mathrm{mg} /$ heifer during the last 29 to $38 \mathrm{~d}$ of the finishing period in combination with melengestrol acetate to feedlot heifers will increase final BW, improve ADG, and improve feed efficiency compared with feeding melengestrol acetate alone. Feeding Optaflexx in combination with melengestrol acetate had variable impacts on carcass quality. Optaflexx appears to have no effect on fat thickness, KPH, or empty body fat compared with heifers fed melengestrol acetate alone.

\section{ACKNOWLEDGMENTS}

The authors thank Jeff Rudolph (Hi-Gain Feedlot, Farnum, NE) and Kendall Karr and Mark Branine (Cactus Feeders, Amarillo, TX) for their involvement and assistance in helping with the data collection, analysis, and overall progression of the 2 experiments.

\section{LITERATURE CITED}

Abney, C. S., J. T. Vasconcelos, J. P. McMeniman, S. A. Keyser, K. R. Wilson, G. J. Vogel, and M. L. Galyean. 2007. Effects of ractopamine hydrochloride on performance, rate, and variation in feed intake, and acid-base balance in feedlot cattle. J. Anim. Sci. 85:3090.

Bloss, R. E., J. I. Northam, L. W. Smith, and R. G. Zimbelman. 1966. Effects of oral melengesterol acetate on performance of feedlot cattle. J. Anim. Sci. 25:1048.

Boggs, D. L., and R. A. Merkel. 1993. Beef carcass evaluation, grading, and pricing. p. 105 in Live Animal Carcass Evaluation and Selection Manual. D. L. Boggs and R. A. Merkel, ed. Kendall Hunt Publishing Co., Dubuque, IA.

Crouse, J. D., B. D. Schanbacher, H. R. Cross, S. C. Seidemand, and S. B. Smith. 1987. Growth and carcass traits of heifers as affected by hormonal treatment. J. Anim. Sci. 64:1434.

Gruber, S. L., J. D. Tatum, T. E. Engle, M. A Mitchell, S. B. Laudert, A. L. Schroeder, and W. J. Platter. 2007. Effects of ractopamine on growth performance and carcass characteristics of feedlot steers differing in biological type. J. Anim. Sci. 85:1809.

Guiroy, P. J., L. O. Tedeschi, D. G. Fox, and J. P. Hutcheson. 2002. The effects of implant strategy on finished body weight of beef cattle. J. Anim. Sci. 80:1791.

Kreikemeier, W. M., and T. L. Mader. 2004. Effects of growth-promoting agents and season on yearling feedlot heifer performance. J. Anim. Sci. 82:2481.
Lauderdale, J. W. 1983. Use of MGA (melengesterol acetate) in animal production. p. 193 in Animal Production: Public Health Aspects, Analytical Methods and Regulation. Off. Int. Epizooties, Paris, France.

Laudert, S. B., G. J. Vogel, A. L. Schroeder, W. J. Platter, and M. T. Van Koevering. 2004. The effect of Optaflexx on growth performance and carcass traits of steers. Optaflexx Exchange: Scientific Update No. 4. Elanco Animal Health, Greenfield, IN.

MacDonald, J. C., T. J. Klopfenstein, G. E. Erickson, and K. J. Vander Pol. 2007. Changes in gain through the feeding period. Nebraska Beef Rep. MP 90:55.

Mersmann, H. J. 1998. Overview of the effects of $\beta$-adrenergic receptor agonist on animal growth including mechanisms of action. J. Anim. Sci. $76: 160$

Morgan, J. B. 1997. Implant program effects on USDA beef carcass quality grade traits and meat tenderness. Symposium: Impact of Implant on Performance of Cattle Beef Cuts. Oklahoma Agric. Exp. Sta. P-957:147.

Owens, F. N., P. Dubeski, and C. F. Hanson. 1993. Factors that alter the growth and development of ruminants. J. Anim. Sci. 71:3138.

Quinn, M. J., C. D. Reinhardt, E. R. Loe, B. E. Depenbusch, M. E. Corrigan, M. L. May, and J. S. Drouillard. 2008. The effects of ractopaminehydrogen chloride (Optaflexx) on performance, carcass characteristics, and meat quality of finishing feedlot heifers. J. Anim. Sci. 86:902.

Schroeder, A. L., D. M. Polser, S. B. Laudert, and G. J. Vogel. 2003a. The effect of Optaflexx on growth and performance and carcass traits of steers. Optaflexx Exchange: Scientific Update No. 1. Elanco Animal Health, Greenfield, IN.

Schroeder, A. L., D. M. Polser, S. B. Laudert, and G. J. Vogel. 2003b. The effect of Optaflexx on growth and performance and carcass traits of heifers. Optaflexx Exchange: Scientific Update No. 2. Elanco Animal Health, Greenfield, IN.

Simms, D. D., T. B. Goehring, R. T. Brandt Jr., G. L. Kuhl, J. J. Higgins, S. B. Laudert, and R. W. Lee. 1988. Effect of sequential implanting with zeranol on steer lifetime performance. J. Anim. Sci. 66:2736.

Sissom, E. K., C. D. Reinhardt, J. P. Hutcheson, W. T. Nichols, D. A. Yates, R. S. Swingle, and B. J. Johnson. 2007. Response to ractopamine$\mathrm{HCl}$ in heifers is altered by implant strategy across days on feed. J. Anim. Sci. 85:2125.

Walker, D. K., E. C. Titgemyer, J. S. Drouillard, E. R. Loe, B. E. Depenbusch, and A. S. Webb. 2006. Effects of ractopamine and protein source on growth performance and carcass characteristics of feedlot heifers. J. Anim. Sci. 84:2795.

Winterholler, S. J., G. L. Parsons, D. K. Walker, M. J. Quinn, J. S. Drouillard, and B. J. Johnson 2007. Effect of feedlot management system on response to ractopamine- $\mathrm{HCl}$ in yearling steers. J. Anim. Sci. 85:413. 